\title{
PENERAPAN SISTEM AKUNTANSI SYARIAH DALAM ASURANSI SYARIAH DI INDONESIA
}

\author{
Adriandi Kasim \\ Institut Agama Islam Negeri Manado, Sulawesi Utara, Indonesia, Jl. Dr. S.H. \\ Sarundajang Kawasan Ring Road I Kota Manado, 95128 \\ E-mail: adriandikasim@iain-manado.ac.id
}

\begin{abstract}
Perkembangan ekonomi dunia yang semakin pesat telah menghasilkan berbagai macam perusahaan dan lembaga-lembaga keuangan di Indonesia, baik itu bank ataupun non bank. Sejalan dengan perkembangan tersebut juga memicu pemikiran masyrakat muslim akan keberadaan serta aktivitas dari perusahaan dan lembaga keuangan. masyrakat muslim meragukan aktivitas lembaga keuangan, sehingga berdirilah lembaga keuangan dengan basic syariah. Namun perkembangan lembaga keuangan syariah yang semakin pesat juga memicu masyarakat akan perlakuan akuntansinya yang sama dengan lembaga keuangan konven lainnya, sehingga ditetapkanlah sistem akuntansi syariah untuk lembaga keuangan syariah. Dalam hal ini penulis membahas sistem akuntansi syariah dalam asuransi syariah dengan menggunakan metode penelitian jenis kajian yang datanya di ambil dari buku hingga jurnal ilmiah. Hasil diskusi yang penulis peroleh pada penelitian artikel kali ini yaitu Akuntansi syariah merupakan proses pencatatan, pernggolongan, pengikhtisaran dan pelaporan keuangan di dalam satu perusahaan selama periode tertentu yang mengacu pada syariat islam. Sistem Akuntansi dalam asuransi yang berbasis syariat terdapat pada perlakuannya, prinsipnya yakni keadilan, dan penerapannya. Berbeda dengan akuntansi pada umumnya, akuntansi syariah mengutamakan prinsip-prinsip syariah. penerapan akuntansi pada asuransi syariah salah satunya yaitu diakui dalam laporan keuangan periode selanjutnya apabila perolehan premi insurance tersebut terjadi sebelum tanggal transaksi. Dari hasil tersebut penulis menyimpulkan bahwasannya asuransi syariah sudah menerapkan akuntansi sesuai dengan syariat Islam yakni akuntansi syariah. Akuntansi syariah ini sangat penting dalam pembuatan laporan keuangan pada asuransi syariah dan juga lembaga syariah lainnya. Semakin luas kita memahami konsep akuntansi syariah maka akan semakin baik pula pelaporan yang akan kita buat.
\end{abstract}

Kata kunci: Akuntansi; Asuransi; Syariah. 


\section{PENDAHULUAN}

Seiring berjalannya perkembangan ekonomi dunia dari masa ke masa, kini telah mengalami modifikasi dan kemajuan beserta dengan munculnya teknologi modern. Begitu banyak dampak postif dan juga negatif dari perkembangan teknologi tersebut yang kini sangat pelik untuk menentukan yang benar dan mana yang salah, dan karena hal tersebutlah, bukan hanya membawa kebaikan namun terkadang juga dapat menyesatkan banyak orang. Dalam hal ini, perkembangan ekonomi yang berkembang beriringan dengan teknologi tentu saja dapat mempengaruhi keadaan masyarakat terutama masalah kesenjangan ekonomi.

Dalam hukum islam, melakukan ativitas perekonomian atau disebut dengan muammalah merupakan suatu hal yang fitrah bagi manusia dan dasar hukumnya adalah boleh (mubah). Namun dalam hal ini tidak semua aktivitas ekonomi dibenarkan oleh hukum islam, yaitu aktivitas yang di dalamnya menimbulkan kezaliman, ketidakadilan atau hal lainnya yang mendatangkan mudharat bagi banyak orang. Hal ini biasanya terjadi pada perusahaan-perusahaan atau lembagalembaga teutama lembaga keuangan.

Setiap perusahaan atau lembaga-lembaga terutama lembaga dibidang jasa keuangan baik itu dari perbankan atau non perbankan diwajibkan untuk membuat dan menyajikan laporan yang menggambarkan kondisi keuangan setiap kurun waktu tertentu, biasanya pada akhir bulan ataupun akhir tahun sesuai dengan kebijakan dari lembaga tersebut atau dalam hal ini dinamakan akuntansi. Akuntansi adalah seni pencatatan, yang dimana dalam hal ini dapat menghasilkan suatu keterangan tentang konisi financial sebuah perusahaan. Keterangan dari financial tersebut yang dinamakan hasil proses akuntansi. Untuk tujuan dari pembuatan pembukuan keuangan ini adalah untuk memberikan penjelasan terkait posisi keuangan perusahaan sebagai tanggung jawab dalam aktivitas keuangannya, baik dalam hal penerimaan dan pengeluaran kas perusahaan. Laporan keuangan ini juga berguna bagi masyarakat dan pihak-pihak yang membutuhkan. Laporan keuangan ini disusun berdasarkan PSAK yang telah ditetapkan di Indonesia.

Asuransi syariah ini merupakan salah satu lembaga keuangan juga wajib membuat laporan keuangan yang tentu saja juga berpedoman pada PSAK 108. Dalam hal ini, kita perlu mengetahui bahwasannya akuntansi sangatlah penting bagi perusahaan, terlebih khusus pada asuransi syariah yang tujuannya membangun kepercayaan nasabah. Akan tetapi, asuransi syariah dalam perkembangannya yang cukup pesat tidak diikuti oleh pendukung lainnnya, seperti kurangnya ketanagakerjaan yang ahli dalam bidang syariah di dalam asuransi syariah, yang menimbulkan banyak nasabah yang tidak mengerti akan konsep yang terdapat didalamnya, terutama berkaitan dengan kontrak atau akad yang ada dalam asuransi syariah. Karena sebab itulah, di Indonesia ditetapkan suatu pedoman terkait akuntansi yang menjadi standar lembaga asuransi basic syariah yang terdapat pada ketentuan Dewan Syariah Nasional nomor 21 tahun 2001. Ketentuan inilah yang menjamin akan kesesuaian asuransi dengan syariat islam, maka ditetapkan juga PSAK No. 108 untuk menetapkan perlakuan akuntansi dalam insurance syariah. 


\section{METODE PENELITIAN}

Pada penelitian artikel paper kali ini, penulis menggunakan pendekatan atau metode kajian pustaka yang hasil pembahasannya diperoleh dengan cara mengumpulkan hasil data dari buku hingga jurnal ilmiah, yang tentu saja berkenaan dengan judul artikel yang penulis kemukakan dengan tujuan untuk dipelajari dan dipahami dengan baik lagi tentang konsep dasar akuntansi syariah dalam asuransi syariah di Indonesia.

\section{HASIL DAN PEMBAHASAN}

Akuntansi pada umumnya berdasarkan AICPA yakni organisasi Amerika yang terdiri dari ahli akuntan bahwasannya akuntansi adalah suatu kegiatan dari penulisan, pengidentifikasian, pengikhtisaran dan pengukuran transaksi melaui aktivitas perusahaan yang berkenaan dengan financial untuk pembuatan laporan keuangan suatu entitas atau peruasahaan. Sedangkan definisi akuntansi berdasarkan AMA (American Accounting Assosiation) yaitu suatu proses mengkaji, menggolongkan, mengikhtisarkan, serta membuat pelaporan informasi keuangan untuk dijadikan suatu pertimbangan dalam pengambilan keputusan yang efektif bagi pengguna untuk kepentingan pihak-pihak yang membutuhkan (Saputra, 2018).

Istilah dari akuntansi yang lainnya yakni al-Muhasabah yang merupakan istilah dari bahasa arab yang artinya menghitung. Sedangkan ahsaba artinya menjaga serta Ihtisaba yang artinya mengasakan ridho Allah Swt dunia dan akhirat, dan juga berarti sebagai sebuah pertanggungjawaban. Pada kesimpulannya akuntansi adalah sebuah proses mencatat, menggolongkan, mengikhitsarkan serta melaporkan segala aktivitas keuangan. Kemudian, untuk arti kata syariah itu sendiri adalah kesesuaian dengan aturan-aturan Allah atau prinsip-prinsip Islam. Jadi, definisi akuntansi syariah adalah suatu proses mencatat, mengklasifikasi mengikhtisarkan serta melaporkan kegiatan keuangan berdasarkan prinsip-prinsip Islam. Prinsip tersebut antara lain prinsip kepercayaan atau amanah dan prinsip keabsahan (AC, 2014).

\section{Teori dan Konsep Dasar Akuntansi Syariah}

Teori adalah suatu kajian tentang konseptual dan aliran filsafat sama-sama memiliki keterkaitan, keterkaitan tersebut dapat menciptakan kerangka atau susunan acuan dari suatu bidang pengetahuan tertentu. Dengan demikian, teori akuntansi syariah adalah suatu penalaran dari suatu kerangka acuan yakni prinsipprinsip akuntansi syariah beserta pedoman bagi perkembangan praktiknya. Tujuan akuntansi syariah yaitu untuk mengukur pengembangan praktik akuntansi yang sehat berdasarkan prinsip syariah.

Konsep dasar akuntansi syariah atau dikenal dengan asumsi akuntansi syariah adalah suatu pernyataan atau pengakuan yang keabsahannya tidak perlu diragukan lagi. Hal ini dikarena telah balancenya laporan keuangan beserta sesuai dengan tujuan dari laoporan keuangan tersebut yakni yang menggambarkan 
lingkungan ekonomi, sosial, dan hukum sebagaimana akuntansi beroperasi. Menurut pandangan Harahap, beliau mengemukakan bahwa akuntansi Islam pasti ada dengan cara menggunakan pendekatan perbandingan antara konsep syariat dengan konsep akuntansi secara kontomporer. Beliau menyimpulkan bahsawannya nilai-nilai syariah terdapat didalam akuntansi, dan akuntansi terdapat dalam hukum, muammalat dan di dalam sejarah islam. (Sari, 2014).

\section{Dasar Hukum Akuntansi Syariah}

Jika di perhatikan dengan seksama, dasar hukum akuntansi syariah terdapat di dalam Q.S Al-Baqarah: 282, di dalam ayat ini Allah menjelaskan tentang fungsi dari pencataan beserta hikmahnya. Dalam ayat ini Allah menyuruh orang-orang yang bertakwa kepada Allah untuk membuat catatan tertulis mengenai aktivitas muammalahnya.

Selain itu dasar hukum konsep akuntansi juga terdapat dalam Q.S AsySyu'ara: 181-184 yaitu menjelaskan tentang penyempurnaan ukuran timbangan dengan baik, larangan merugikan orang lain atau mengambil hak-hak yang bukan miliknya, serta untuk senantiasa bertakwa kepada Allah Swt. Dan juga terdapat dalam Q.S Al-Israa' : 35 yaitu menjeleskan tentang bentuk pengukuran yang berbentuk pos-pos yang di buat di dalam neraca (AC, 2014).

\section{Perkembangan Akuntansi Syariah di Indonesia}

Kemunculan Akuntansi didasari oleh beberapa faktor yakni sistem ideologi dan ekonomi di dalam negara. Di Indonesia, akuntansi ini pun berkembang dari waktu ke waktu, dan di Indonesia akuntansi inipun di pengaruhi oleh perkembangan pemikirannya umat muslim, sehingga hal ini mendorong adanya perkembangan ekonomi berbasis syariah sebagai bentuk gerakan nyata dari kosep pemikiran umat islam, dan hal ini juga yang menjadi faktor terbentuknya penerapan sistem akuntansi syariah. Lembaga-lembaga keuangan islam, baik itu lembaga perbankan syariah ataupun yang bukan perbankan dan persepsi umat islam merupakan salah satu faktor perkembangan akuntansi syariah terbesar dan paling berpengaruh. Akuntansi syariah ini berkembang karena adanya keraguan masyarakat muslim serta para akuntan terhadap sistem kerja akuntansi konvensional yang mungkin bertentangan dengan syariat islam.

Salah satu penyebab yang paling utama yang mendorong akan perkembangan akuntansi menjadi akuntansi sesuai syariah adalah berkembangnya LKS dengan ratio yang cukup pesat. Namun pertumbuhan dan perubahan yang begitu pesat tersebut tidaklah berjalan dengan baik melainkan banyak menimbulkan permasalahan serta tantangan oleh masyarakat dan lembaga keuangan syariah, salah satunya adalah bagaimana perlakuan sistem akuntansinya yang merupakan suatu proses pertanggungjawaban aktivitas dari setiap lembaga atau perusahaan. Berbagai permasalahanpun muncul dalam LKS diantaranya berkenaan dengan aspek teori, operasional serta penerapannya. Aspek teoritis tersebut berkenaan dengan pengembangan prinsip serta fungsi keuangan dalam pembagian laba rugi. 
Pada operasionalnya berkenaan dengan krativitas dan inovasi serta risk control. Sedangkan untuk penerapannya itu sendiri yaitu kesesuaian aturan dan keadaan masyarakat sekarang (Apriyanti, 2017).

\section{Definisi Aasuransi Syariah}

Asuransi atau juga dikenal dengan ta'min (berasal dari bahasa arab) yaitu pertanggungan. Menta'minkan sesuatu artinya memberikan sejumlah uang atau membayar sebuah kewajiban tertentu, atau dengan dengan kata lain menanggung sesuatu sesuai dengan kaidah awal akad. Asuransi ini merupakan sebuah tanggungan untuk menjamin risk yang akan datang.

Di Indonesia definisi asuransi syariah yang dikemukakan oleh DSN adalah suatu lembaga yang kegiatannya saling membantu sejumlah pihak yang ikut serta dalam produk asuransi syariah baik dalam bentuk bisnis ataupun derma melaui kesepakatan syariah. Dari definisi DSN ini dapat disimpulkan bahwasannya asuransi syariah mengandung unsur tolong menolong dan melindungi. Sedangkan Istilah asuransi lainnya adalah suatu manajemen risk yang sesuai dengan kaidah syariat Islam, yang dalam kegiatannya melibatkan para peserta asuransi.

Dibentuknya lembaga asuransi khusus syariah ini bertujuan untuk membantu para peserta, memberikan jaminan akan risiko yang terjadi dimasa mendatang. Dengan adanya asuransi syariah ini dapat bermanfaat bagi para masyarakat yang ikut serta dalam produk-produk asuransi syariah. Perlu diketahui bahwannya prinsip asuransi syariah ialah saling menguntungkan bagi para peserta asuransi syariah (Tho'in \& Anik, 2017).

\section{Regulasi Hukum Asuransi Syariah di Indonesia}

Di Indonesia, aktivitas asuransi berbasis syariah kini telah mendapat pengakuan serta tempat yang layak baik dari segi sosiologis, yuridis maupun filosofis. Secara sosiologis artinya hukum tetap berlaku meskipun masyarakat tidak setuju, hal ini disebut dengan teori kekuasaan, atau hukum berlaku dan diterima oleh masyarat, hal ini disebut teori pengakuan. Selain itu juga asuransi dapat belaku secara filosofis apabila telah mencapai kaidah yang dicita-citakan.

Dari segi yuridis pedoman operasional asuransi berbasis syariah mengacu pada penetapan Dewan Syariah Nasional Majelis Ulama Indonesia Nomor 21 Tahun 2001 . Isi fatwa tersebut ialah asuransi syariah adalah sebuah lembaga yang dalam kegiatannya yaitu untuk usaha saling membantu antar sesama peserta ataupun lembaga asuransi itu sendiri berdasarkan kesepakatan awal. Akad yang sesuai dengan syariah yaitu yang tidak memiliki unsur penipuan, ketidakjelasan, perjudian, riba. dan hal lainnya yang diharamkan oleh syariat. Penetapan peraturan yang diakui atau yang memiliki kekuatan hukum nasional Indonesia yakni UUD Negara RI Tahun 1945, PP Pengganti UU, PP, Pepres, dan Perda. Sehingga dalam hal ini penetapan yang dikeluarkan oleh DSN mengenai pedoman asuransi syariah belum mempunyai kekuatan hukum di Indonesia. 
Asuransi syariah yang berada di dalam Indonesia telah tercatat terdapat 42 asuransi syariah, yang terdiri dari 2 asuransi umum syariah beserta 20 unit asuransi umum syariah, dan terdapat 3 asuransi jiwa syariah beserta 17 unit asuransi jiwa syariah. Catatan tersebut diketahui berdasarkan hasil data dari penelitian oleh lembaga Asosiasi Asuransi Syariah. Dari hasil data yang diteliti oleh Asosiasi Asuransi Syariah tersebut menjadi sebuah bukti bahwasannya asuransi syariah telah diakui keberadaannya oleh masyarakat di Indonesia.

Di Indonesia, terbentuknya asuransi syariah juga didasari pada Q.S alMa'idah ayat 2, dalam ayat tersebut Allah memerintahkan kepada manusia untuk melakukan kebaikan seperti saling tolong menolong dan menjauhi perbuatan yang mendatangkan mudharat serta Allah memerintahkan manusia untuk senantiasa bertakwa kepadanya (Effendi, 2016).

\section{Konsep Asuransi Syariah di Indonesia}

Asuransi ialah lembaga yang menggunakan sistem agregrat atau yang dimana seluruh pesertanya memberikan dana atau donasi untuk digunakan dalam pembayaran klaim risk tertentu. Hal ini berdasarkan PSAK 108 atau pernyataan standar akuntansi keuangan. Donasi tersebut memiliki syarat dan merupakan hak milik peserta bersama, bukan pendapatan perusahaan. Dengan kata lain, maksud dari PSAK 108 yaitu peserta asuransi menyetor uang sesuai akad untuk dipakai ketika terjadi risk atau bahaya pada peserta. Dalam hal ini, lembaga asuransi berdiri atas dasar kerja sama tolong menolong. Sedangkan asuransi pada masa kontemporer ini adalah peserta menyetorkan sejumlah uang dengan 2 cara yaitu sebagai tabungan dan dana kebijakan. Tabungan yaitu amanat dari peserta dan profit sharing dari net investment income (Meiliana, 2015).

\section{Akuntansi Transaksi Asuransi Syariah Berdasarkan PSAK 108}

Seorang akuntan dalam proses pembuatan pengakuan, pengukuran, dan penyajian transaksi laporan keuangan wajib berpedoman pada PSAK 108 atau yang kita kenal dengan Pernyataan Standar Akuntansi Keuangan, yang didalam pernyataan tersebut berisikan ketentuan yang berkenaan dengan transaksi kontribusi peserta, surplus, dan cadangan dana kebajikan.

Pernyataan Standar Akuntansi Keuangan 108 tersebut juga berisikan ketentuan dalam penyusunan laporan keuangan, diantaranya yaitu:

1. Bertujuan sebagai pedoman dalam memanajemen pengesahan, perhitungan, pembuatan, dan penyingkapan transaksi yang terjadi di dalam asuransi syariah.

2. Transaksi tersebut berkenaan dengan keikutsertaan peserta, kelebihan, atau penjaminan defisit, penyisihan sisa dana kebajikan.

3. Kesepakatan atau kontrak dalam asuransi syariah yaitu kesepakatan dana kebajikan untuk tolong menolong antar sesama peserta dan kesepakatan 
tijarah atau kesepakatan untuk bisnis antar investor dan pihak asuransi selaku pengelola.

4. Pemenuhan tuntutan atau klaim merupakan dana yang bersumber dari kepemilikan penuh pihak peserta.

5. Partisipasi dana dari para pihak dicatat sebagai income dana kebajikan.

6. Sisa dana kebajikan, surplus, dan defisit dicatat sebagai perubahan sisa dana kebajikan.

7. Perlakuan untuk hasil investasi mengacu pada PSAK.

Perlakuan akuntansi dalam asuransi syariah salah satunya terhadap premi yaitu sebagian dananya diakui sebagai dana tabarru' sedangkan untuk sebagian lainnya dijadikan fee pada pengelola. Dalam hal ini, Pencatatan akuntansinya dicatat terpisah dan kemudian dijadikan satu dalam laporan keuangan. Pencataatn iuran fee tersebut dicatat oleh perusahaan asuransi sebagai fee income, dan pencatatan dana kebajikan dicatat oleh perusahaan sebagai dana kebajikan'. Sedangkan untuk aktivitas hasil investment dicatat sebagai investment income (Muhammad et al., 2017).

Pada penerimaan premi di catat dan di akui perusahaan, kas bertambah sebelah debet dan premi income bertambah sebelah kredit. Pada pemenuhan klaim, maka perusahaan mencatat beban klaim bertambah sebelah debet dan kas berkurang sebelah kredit. Pada investasi, perusahaan mencatat efek, obligasi, reksadana bertambah sebelah debet dan kas berkurang sebelah kredit. Sedangkan untuk hasil investasi, dicatat kas bertambah sebelah debet dan pendapatan investasi bertambah sebelah kredit.

\section{Perlakuan Akuntansi Syariah dalam Asuransi Syariah}

Pengakuan Awal, partisipasi para pihak diakui sebagai pendapatan dana kebajikan berdasarkan jangka waktunya yaitu sebagai berikut: (1) Pada kesepakatan berjangka pendek, partispasi para pihak diakui sebagai pendapatan dana kebajikan di awal kesepakatan; (2) Pada kesepakatan berjangka panjang, partisipasi para pihak diakui sebagai pendapatan dana kebajikan di akhir kesepakatan atau diakui ketika batas pembayaran telah jatuh tempo.

Pengukuran, penetapan dan pengukuran jumlah surplus underwriting (kelebihan penjaminan) yaitu: (1) Seluruh kelebihan penjaminan dijadikan tambahan saldo dana tabarru'; (2) Sebagian kelebihan penjaminan dijadikan tambahan daldo dana tabarru' dan sebagiannya disalurka ke masing-masing peserta; (3) Sebagian kelebihan penjaminan dijadikan tambahan saldo tabarru', dan sebagiannya disalurkan kepada masing-masing peserta beserta perusahaan pengelola.

Penyisihan Teknis: (1) Pemenuhan tuntutan yang terjadi dimasa mendatang pada kesepakatan yang berjangka pendek diambil dari jumlah penyisihan yang belum menjadi hak pada masa sebelumnya; (2) Pemenuhan tuntutan yang terjadi dimasa mendatang pada kesepakatan jangka panjang diambil dari kesepakatan polis 
sebelumnya; (3) Pemenuhan tuntutan yang terjadi dimasa berjalan atau periode berjalan, baik pada kesepakatan berjangka pendek atau panjang, diambil dari jumlah penyisihan periode berjalan; (4) Jumlah penyisihan periode berjalan yang diambil untuk pemenuhan tuntutan masa berjalan diambil dari penyisihan tuntutan yang tejadi akan tetapi belum dilaporkan; (5) Pengukuran penyisihan partisipasi yang belum menjadi hak diukur terpisah dari pertanggungan dan diukur sesuai dengan yang telah disepakati; (6) Pengukuran penyisihan polis diukur dengan meghitung perkiraan pembayaran dan jumlah hasil investasi serta dana kebajikan; (7) Pengukuran klaim yang sedang outsanding oleh pengelola harus sesuai dengan tuntutan yang terjadi, kemudian disampaikan dan dibuat dalam laporan; (8) Klaim yang sudah terjadi tetapi belum diukur, dihitung pada saat pelaporan dengan mempertimbangkan pengalaman sebelumnya dan klaim pada saat ini.

Penyajian: (1) Penyisihan teknis disajikan terpisah pada bagian liability dalam neraca; (2) Penyisihan saldo dana kebajikan dan investasi disajikan terpisah dari hutang dan modal dalam neraca.

Pengungkapan: (1) Partisipasi yang diperoleh beserta modifikasinya dan pembatalan tanggungan beserta akibatnya diungkapkan dalam kebijakan akuntansi; (2) Pengelola mengungkapan hak untuk menagih partisipasi pada para pihak; (3) Pengelola mengungkapkan informasi pemaparan partisipasi para pihak sesuai dengan jenis asuransi; (4) Kebijakan perlakuan surplus (Ifhan Sholihin, 2013).

\section{Penerapan Akuntansi Syariah pada Asuransi Syariah}

Salah satu penerapan atau pelaksanaan sistem akuntansi syariah yang sering dilaksanakan oleh asuransi syariah adalah syarikat takaful. Pada dasarnya terdapat kemiripan antara akuntansi syarikat takaful dan asuransi konven, yaitu sama-sama terdapat tahapan yang khusus dan ketentuan usaha yang sudah ditentukan dalam takaful Act 1984 dan asuransi konven yang sudah ditetapkan dalam asuransi 1963, karena asuransi takafulpun juga disebarluaskan dengan persepsi usaha. oleh karena itu, untuk mencapai persepsi usaha yang telah ditentukan oleh syariat, maka akuntansi takaful juga dibuat secara syariah. Dalam hal ini tentu saja tidak sama dengan akuntansi yang ada dalam asuransi konven.

Ada beberapa prinsip-prinsip yang terdapat pada akuntansi takaful dan akuntansi pada asuransi konven, yaitu antara laiin:

1. Diakui dalam laporan keuangan periode selanjutnya apabila perolehan premi insurance tersebut terjadi sebelum tanggal transaksi.

2. Jumlah premi penutupan insurance yang belum terpakai pada periode berjalan diakui sebaga dana cadangan.

3. Sebelum net profit entitas pada periode berjalan ditentukan maka harus memeriksa kembali pembayaran klaim pada pemenuhan dana reserve.

4. Retakaful. Sama halnya dengan konvensional insurance, takaful juga memiliki beberapa tantangan dalam pemenuhan klaim yang diajukan oleh para peserta. 
5. Rekening perolehan dari takaful dan surplus cicilan setiap bulannya dihitung dan diakui sebagai dana takaful pada last year. (Suparmin, 2019)

\section{KESIMPULAN}

Akuntansi syariah di Indonesia itu sendiri dilatarbelakangi oleh keraguan umat muslim akan ketentuan akuntansi konvensional yang mungkin saja tidak sesuai dengan akuntansi konvensional sehingga ditetapkanlah akuntansi syariah. Akuntansi syariah di dalam asuransi syariah merupakan proses pencatatan, pengkalsifikasian, pengikhtisaran, dan pelaporan keuangan yang berbasis syariah. Prinsip akuntansi yan digunakan dalam asuransi syariah yaitu prinsip pertanggungjawaban, prinsip keadilan, prinsip amanah. Pedoman penyusunan akuntansi dalam asuransi syariah ini yaitu terdapat dalam PSAK 108. Di dalam PSAK 108 termuat kerangka dasar penyusunan akuntansi syariah. Proses akuntansi syariah ini akan menghasilan suatu laporan keuangan dalam asuransi syariah, yang menunjukan arus kas, laba rugi, perubahan modal, beserta posisi keuangan lembaga keuangan syariah. Sedangkan untuk laporan keuangan itu sendiri berfungsi sebagai pertanggung jawaban atas kegiatan keuangan dari lembaga asuransi syariah tersebut. Untuk transaksi akuntansi syariah di dalam asuransi syariah itu yakni transaksi yang berkenenaan dengan kontribusi peserta baik dalam investasi ataupu pada dana kebajikan atau dana tabarrui8'. Sedangkan untuk kesepakatan yang terdapat dalam asuransi syraiah yaitu kesepakatan dana kebajikan dan kesepakatan investasi atau bisnis. Sedangkan untuk perlakuan akuntansi syariah dalam asuransi syariah di Indonesia itu sendiri mengacu pada PSAK. Untuk Perlakuan akuntansinya yaitu terdapat pengakuan, pengukuran, penyajian teknis, dan pelaporan. Pengakuan terhadap akad jangka panjang dan akad jangka pendek juga berbeda sesuai dengan peristiwa terjadi baik sudah tajuh tempo atau sebelum jatuh tempo. Dan pelaksanaan dan penerapan akuntansi syariah yang dominan di dalam asuransi syariah di Indonesia adalah syarikat takaful.

\section{REFERENSI}

AC, A. M. (2014). AKUNTANSI SYARIAH; Pendekatan Normatif, Historis dan Aplikatif. IQTISHADIA: Jurnal Ekonomi \& Perbankan Syariah. https://doi.org/10.19105/iqtishadia.v1i1.366

Apriyanti, H. W. (2017). AKUNTANSI SYARIAH: SEBUAH TINJAUAN ANTARA TEORI DAN PRAKTIK. Jurnal Akuntansi Indonesia. https://doi.org/10.30659/jai.6.2.131-140

Effendi, A. (2016). ASURANSI SYARIAH DI INDONESIA (Studi Tentang Peluang ke Depan Industri Asuransi Syariah). Wahana Akademika: Jurnal Studi Islam Dan Sosial. https://doi.org/10.21580/wa.v3i2.1145

Meiliana, R. (2015). Evaluasi Kesesuaian Psak 108 Akuntansi Transaksi Asuransi Syariah Dengan Mengacu Kepada Alquran Dan Hadist. Jurnal Manajemen Magister Darmajaya.

Muhammad, R., Tinangon, J. J., \& Runtu, T. (2017). ANALISIS AKUNTANSI DANA INVESTASI ASURANSI UMUM SYARIAH DAN KONVENSIONAL SERTA PERLAKUAN TERHADAP HASIL INVESTASI (Studi Kasus Pada PT. Asuransi Asei Indonesia). GOING 
CONCERN : JURNAL RISET AKUNTANSI. https://doi.org/10.32400/gc.12.2.17397.2017

Saputra, D. (2018). Analisis Penerapan Akuntansi Pada Usaha Toko Kain Pakaian Di Di Pasar Bawah-Pekanbaru. Journal of Chemical Information and Modeling.

Sari, N. (2014). Akuntansi Syari'ah. Jurnal Khatulistiwa.

Tho'in, M., \& Anik, A. (2017). ASPEK-ASPEK SYARIAH DALAM ASURANSI SYARIAH. Jurnal Ilmiah Ekonomi Islam. https://doi.org/10.29040/jiei.v1i01.28

Ifhan Sholihin, A. (2013). Buku Pintar Ekonomi Syariah. Grammedia Pustaka

Suparmin, A. (2019). Asuransi Syariah Konsep Hukum dan Operasionalnya. Uwais Inspirasi Indonesia. 